\title{
Is Sugar-Free Chewing Gum Really Good For Your Teeth?6 Facts about It Here
}

\section{Daniel Craig Hetrelezis*}

Australia

Submission: January 01, 2017; Published: July 13, 2017

*Corresponding author: Daniel Craig Hetrelezis, 4/21 Vermont Rd, Mowbray, TAS, Australia, Tel: 7249, 03 63264368, Email: hetrel@gmail.com

\section{The good's}

Chewing gum stimulates saliva flow: Saliva contains many tooth-protective molecules including calcium which can help keep the enamel strong and prevent tooth-nasty bacteria from sticking to tooth surfaces.

Chewing gum clears debris from your mouth: the increased volume of saliva helps wash away food particles, keeping away anything that tooth-nasty bacteria can get their hands on.

Chewing gum helps with bad breath: dry mouth means sulfur made from bacteria on the tongue can evaporate easier. Sulfur evaporation from the tongue creates a bad smell.

\section{The bad's}

Excessive gum chewing can aggravate the jaw joint: when you chew gum excessively, the jaw and the joint it sits in becomes tender and aggravated. Try to limit chewing to no more than 15 minutes, 4 times a day, between meals.

Chewing gum with a pre-existing jaw problem can worsen it: sometimes it better to let a sore jaw rest.

Chewing gum doesn't substitute good brushing and cleaning. There are a lot of hard to reach places in the mouth that just need a good old brush and floss. It's like dirty dishes that need to be scrubbed before they're put into a dishwasher.

\section{Conclusion}

Sugar-free chewing gum is good for your teeth, but avoid using it for long durations. If your jaw becomes sore or is already sore, see a dentist about it and discontinue it's use immediately. And don't forget to brush and floss.

\section{Your next submission with Juniper Publishers will reach you the below assets}

- Quality Editorial service

- Swift Peer Review

- Reprints availability

- E-prints Service

- Manuscript Podcast for convenient understanding

- Global attainment for your research

- Manuscript accessibility in different formats

( Pdf, E-pub, Full Text, Audio)

- Unceasing customer service

Track the below URL for one-step submission https://juniperpublishers.com/online-submission.php 